\title{
Jeroen de Kloet and Anthony Fung, Youth Cultures in China,
}

Cambridge, United Kingdom, Malden, MA, Polity Press, 2017, 229 p.

Ling Minhua

\section{OpenEdition}

\section{Journals}

Electronic version

URL: http://journals.openedition.org/chinaperspectives/7436

ISSN: 1996-4617

\section{Publisher}

Centre d'étude français sur la Chine contemporaine

\section{Printed version}

Date of publication: 1 September 2017

Number of pages: 70

ISSN: 2070-3449

\section{Electronic reference}

Ling Minhua, "Jeroen de Kloet and Anthony Fung, Youth Cultures in China, », China Perspectives

[Online], 2017/3 | 2017, Online since 01 September 2017, connection on 23 September 2020. URL :

http://journals.openedition.org/chinaperspectives/7436

This text was automatically generated on 23 September 2020.

(c) All rights reserved 


\title{
Jeroen de Kloet and Anthony Fung, Youth Cultures in China,
}

Cambridge, United Kingdom, Malden, MA, Polity Press, 2017, 229 p.

\author{
Ling Minhua
}

1 Youth Cultures in China opens with Wen Yiduo's assumption of revolutionary zeal among Chinese youth in the early twentieth century, when China was seized by wars and crises, but it argues that Chinese youth today embrace "no more revolution." Having grown up with market-oriented economic reforms, Chinese youth receive a good level of education, enjoy mass consumption, and share nationalistic sentiments amidst China's resurgence as a global economic and political superpower in the twentyfirst century. Meanwhile, the chinese state has evolved into an effective oneparty regime equipped with an immense bureaucracy, a strong army, and a techsavvy governing apparatus. All these

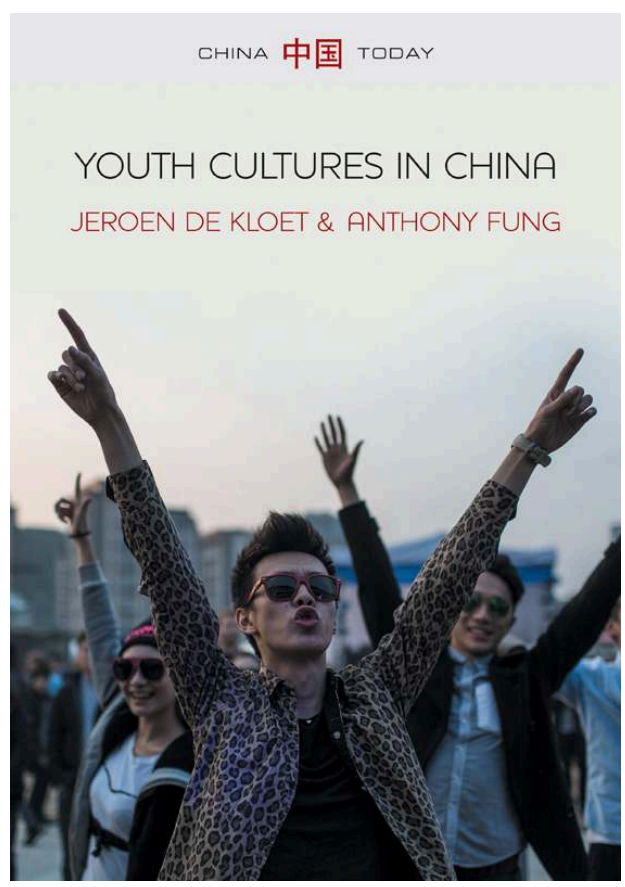
macro changes demand new and nuanced approaches to studying the means and practices of youth culture in contemporary China.

Based on media analysis and ethnographic data collected in major cities in China, including Beijing, Shanghai, and Shenzhen, between 1992 and 2016, the authors depict the multitudes of Chinese youth culture, in which "small interventions, piecemeal changes, occasional resistance and locally specific alternative subjectivities" (p. 21) have merged in the post-reform era. Borrowing anthropologist Appadurai's framework 
for understanding globalisation and modernity, the authors use the notion of "youthscape" to emphasise the constitutive relationships between various social institutions, including the state, family, school, and media, that condition youth experiences and identities.

The Foucauldian notions of power and governmentality are essential to the book's theoretical proposition, especially in Chapter One on the constraints imposed on youth in the family, at school, and by the party-state. China's family planning policies intensify familial ties between the parents and the only child. The nine-year compulsory public schooling system socialises Chinese youth to a rigid disciplinary regime centred on laborious preparation for standardised examinations and upward mobility. The Communist Party and its Youth League also actively cultivate young members to contain political opposition by providing them with advantages in education and employment. The authors argue that these institutions have set up a "cultural firewall of China" (p. 53) preventing external influence and infiltrating the state-sanctioned hegemonic discourses of nationalism and filial piety so that Chinese youth generally adopt pragmatic approaches and "feigned compliance" (p. 56) in public. Any simplistic assumption of Chinese youth being liberated or enabled by the Internet and global culture is questionable.

4 The rest of the book nevertheless credits the agency of Chinese youth within structural and discursive constraints. It details how various youth groups mobilise creative strategies to negotiate with different authorities and gain their own spaces of expression, especially through new media. Chapter Two examines music, fashion, and digital styles, in which Chinese youth appropriate Western cultural forms to assert their individuality and aspirations. Chapter Three focuses on the localisation of television shows and pop music from Japan and South Korea that has carved out spaces for Chinese youth to seek fun and express youthfulness without much state monitoring, at least for now. Chapter Four examines the links between youth and gender and sexuality by highlighting both the dominance and disruption of heteronormative discourse as seen in romantic comedy, queer culture, and feminist activism. Chapter Five discusses media representation of rural-to-urban migrant youth - a marginalised social group because of China's socialist hukou system - as well as these migrants' usage of media technology and participation in cultural production.

5 The above four chapters reveal how "governmentality, biopolitics, and technologies of the self are mutually constitutive" (p. 195). The ways in which the norms, regulations, and discourses are defined and normalised are far from straightforward. Meanwhile, Chinese youth are neither victims nor martyrs of any unified, top-down, overtly oppressive power. They often internalise official ideologies and national goals while taking exams, competing for jobs, and conducting themselves in real and virtual spaces. And when they benefit from new digital media to create various youthscapes, imagine different lives, and seize moments of subversion, they are simultaneously exposed to the risks of being governed by factories and the state. As the authors put it, "There is opposition amidst subordination, optimism following domination, and mobility behind relegation" (p. 195). The state and youth hence co-create youth cultures in a paradoxical manner.

6 The plural form of "cultures" in the title serves as an important claim and reminder of the multiplicity and ambiguity of the experiences and subjectivities of Chinese youth today. Nevertheless, the youth discussed in this book are predominantly urban. Rural 
youth who grew up in the countryside and remain in agriculture or work in nearby towns are missing. The book would be more accurately titled as "Youth Cultures in Urban China." Given that forty percent of China's population still lives in the countryside, more studies are needed about rural youth growing up and working in villages and towns that have been undergoing drastic transformations but are largely invisible in media representation and academic study. It would also be interesting to see whether school dropouts or vocational school students who are spared the pressure of the gaokao (university entrance examination) might form more subversive subcultures because of their distance from school authority and state monitoring. After all, youth, as an in-between life stage and an "achievement" (p. 9) via creative tactics, is full of potential. It therefore remains an important question whether Chinese youth will engage in "an ethics of possibility" (p. 201) (in Appadurai's words) in the future, exercising more imagination for greater equity and more freedom if China's economic growth slows down, the unemployment rate rises, or media censorship escalates.

7 In sum, this book makes a timely contribution to studies of youth, media, cultural politics, and Chinese society. De Kloet and Fong, two renowned China media scholars, demonstrate their intimate knowledge of Chinese media and youth culture, seamlessly weaving first-hand data into a synthesis of the vast literature in both Chinese and English. This book will be a good source for researchers and students of China and media studies as well as non-specialist readers.

\section{AUTHOR}

\section{LING MINHUA}

Ling Minhua is an assistant professor at the Centre for China Studies, The Chinese University of Hong Kong, Hong Kong (mhling@cuhk.edu.hk). 